\title{
低発熱形セメントを使用したマスコンクリートの 調合強度の補正に関する考察 \\ STUDY ON CORRECTION OF STRENGTH FOR PROPORTIONING OF MASS CONCRETE USING LOW-HEAT TYPE CEMENT
}

\author{
池内俊之*，桝 田佳寛** \\ Toshiyuki IKEUCHI and Yoshihiro MASUDA
}

\begin{abstract}
Based on the data of strength obtained from experiment, corrections of proportioning strength of mass concrete using low-heat type cement are studied. In case that the age for quality control of the strength of concrete in structure using low-heat portland cement is 28 days, curing under low temperature makes the strength of concrete in structure be lower than expected strength. And for several combinations of the age for proportioning strength of concrete and the age for quality control of the strength of concrete in structure, influence of difference between the two methods of proportioning design is clarified.
\end{abstract}

Keywords: low-heat type cement, mass concrete, fly-ash, mix proportion, strength correction value, $S$ value 低発熱形セメント, マスコンクリート, フライアッシュ, 調合, 強度補正値, $\mathrm{S}$ 值

\section{1.はじめに}

低発熱形セメントは、水和熱を抑制することができるため、部材 断面が大きく、水和熱によって内部温度が大きくなるマスコンクリ 一トに適したセメントである。日本建築学会が制定する「建築工事 標準仕様書 JASS5N 原子力発電所施設における鉄筋コンクリート 工事」（以下、JASS5N という）1）は、主にマスコンクリートを対 象としていることから、水和熱抑制に有効である低発熱形セメント を標淮的なセメントとして取り扱っている。

JASS5N では、コンクリートの種類がマスコンクリートの場合、 調台設計の定め方は、構造体コンクリートの強度管理用供試体の種 類および養生方法に応じて、4つの方法が規定されている。基本的 には 1997 年に改定された日本建築学会「建築工事標準仕様書 JASS5 鉄筋コンクリート工事」（以下、JASS5 という）2）の考え方 を踏樈しているが、JASS5Nの4つの方法では、構造体補正強度お よび養生温度補正強度のうちいずれかを用いて調合強度を補正して いる。

構造体補正強度は、標準養生した管理用供試体の強度と構造体コ ンクリートの強度の差を唯一の補正值（いわゆる $\mathrm{S}$ 值）として算出 される。 $\mathrm{S}$ 值は原則として試験または信頼できる資料によって、そ の都度定めなくてはならず、工事ごとに、あらかじめ部材を模擬し た試験体や簡易断熱盖生供試体等を用いた実騒によって S 值を求め るケースが多い:か。
一方、養生温度補正強度は、構造体コンクリートの養生温度条件 等から決まる補正值掞よび補正倸数の組合せによって算出される。 算出に必要な補正值および補正係数は、主要な低発熱形セメントに ついては実験に基づく研究 4)ータがされており、その成果が JASS5N に標準值や目安值として示されている。また、筆者ら () 11) は、これまで使用実績が少ない低発熱形セメントとして、普通ポル トランドセメントの $30 \%$ をフライアッシュに置換した場合や低熱 ポルトランドセメントを使用した場合について補正值および補正倸 数を提案している。したがって、これらが適用できる場合には、構 造体補正強度を用いる場合と異なり、あらかじめ実験等を行わなく ても調合強度を補正することができる。

上記 2 つの補正方法のどちらを採用したとしても、調合強度は本 来同じとなるはずであるが、実際の構造体コンクリートでの発現強 度から直接的に算出寸る構造体補正強度と、積算温度の考え方に基 づいて補正值および補正係数を定め、それらを組み合わせて求める 養生温度補正強度とは必ずしも一致しない。

本検討は、これまでに得られた実験デー夕を検討資料とし、構造 体補正強度および養生温度補正強度を同一データから算出し、それ らを比較することにより低発熱形セメントを使用したマスコンクリ 一トの調合强度の補正方法について考察するものである。なお、養 生温度補正強度を求めるために必要な補正值および補正係数は、既 に規定もしくは提案されている值を用いる。
* 関西電力侏土木建築室 工修

** 宇都宮大学工学部建設学科 教授. 工博
Office of Civil Eng. and Architecture, The Kansai Electric Power Co., Inc., M. Eng. Prof., Dept. of Architecture and Civil Eng., Faculty of Eng., Utsunomiya Univ., Dr. Eng. 


\section{2. 検討資料}

低発熱形セメントを使用したマスコンクリートの調合強度につい て検討するための資料として、既往文献 ベ11の実験データを用いる。

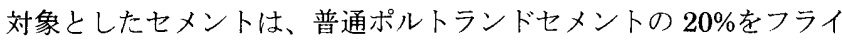
アッシュに置換したもの (FB)、同じく $30 \%$ 置換したもの $(\mathrm{FC}) 、$ 中庸熱ポルトランドセメント $(\mathrm{M})$ 、中庸熱ポルトランドセメントの 18\%をフライアッシュに置換したもの（MF）および低熱ポルトラン ドセメント（L）の 5 種類である。本検討に用いた実験データの概 要を表 1 に示す。

表 1 実験データの概要

\begin{tabular}{|c|c|c|c|}
\hline 実験シリーズ & I & II & III \\
\hline セメント & $\mathrm{FB}, \mathrm{M}, \mathrm{MF}$ & $\mathrm{FB}, \mathrm{M}, \mathrm{MF}$ & FB,FC,L \\
\hline 水セメント比 ${ }^{* 1}$ & $\mathbf{5 5} \%$ & $40 \%, 50 \%$ & $40 \%, 50 \%$ \\
\hline 試験体製作季節 & - & 秋期,冬期,春期,夏期 & 冬期,夏期 \\
\hline 養生方法 & \multicolumn{3}{|c|}{ 標準養生,模擬部材(コア) } \\
\hline 試験材齢 & \multicolumn{3}{|c|}{ 28日,56日(標準養生のみ),91日 } \\
\hline コア強度デー夕数 $* 2$ & 21 & 36 & 70 \\
\hline
\end{tabular}

※1:フライアッシュを混入する場合は全てをセメントとみなす ※2:材齘28日、91日においてそれぞれ表中記載数ずつ

\section{3. 検討方法}

1991 年版 JASS5N までは、調合強度を定める材齢 $\mathrm{m}$ [日]と構造体 コンクリートの強度管理材龄 $\mathrm{n}$ [日]は一致させていたが、2001 年版 JASS5N では、この両者を異なる材齢 $(m \leqq n)$ とすることを認めて いる。本検討では、検討資料とした実験データから $\mathrm{m}$ と $\mathrm{n}$ を組み合 わせて、それぞれについて設計基淮強度（厳密には耐久設計基準強 度と設計基準強度の大きいほうの值であるが、本検討では設計基準 強度について記載する）に対する補正值を算出する。

\section{1 構造体補正強度による補正}

JASS5N において構造体補正強度 $\mathrm{mFs}_{\mathrm{n}}^{\prime}\left[\mathrm{N} / \mathrm{mm}^{2}\right]$ は、(1)式のように 規定されている。

$$
{ }_{m} \mathrm{Fs}_{\mathrm{n}}=\mathrm{F}_{\mathrm{c}}+{ }_{\mathrm{m}} \mathrm{S}_{\mathrm{n}}
$$

ここで $\mathrm{F}_{\mathrm{e}}$ ：設計基準強度 $\left[\mathrm{N} / \mathrm{mm}^{2}\right] 、 \mathrm{mS}_{\mathrm{n}}$ : 材㱓 $\mathrm{m}$ 日での標準養 生供試体の強度と材齢 $\mathrm{n}$ 日での構造体コンクリートの強度との 差による強度の補正值[N/mm²]（JASS5N では、この補正值を $\mathrm{S}$ としているが、本論文では $\mathrm{m}$ と $\mathrm{n}$ を明確にするため JASS5

「19 節 高強度コンクリート」での定義を参考に $\mathrm{mS}_{\mathrm{n}}$ とする。) ここでは、実験で得られた強度データより構造体補正強度の考え 方に基づく補正值 $\mathrm{mS}_{\mathrm{n}}\left[\mathrm{N} / \mathrm{mm}^{2}\right.$ ]を(2)式によって算出する。

${ }_{\mathrm{m}} \mathrm{S}_{\mathrm{n}}={ }_{\mathrm{m}} \mathrm{F}_{\text {stmol }}-{ }_{\mathrm{n}} \mathrm{F}_{\text {cora }}$

ここで、 $\mathrm{mF}_{s t n d}$ : 実験により得られた材齢 $\mathrm{m}$ 日での標準養生供試

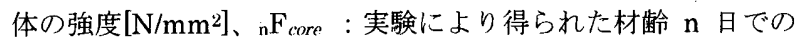
コア供試体の強度 $\left[\mathrm{N} / \mathrm{mm}^{2}\right.$ ]

\section{2 養生温度補正強度による補正}

JASS5Nにおいて養生温度補正強度 ${ }_{\mathrm{m}} \mathrm{F}_{\mathrm{n}}{ }_{\mathrm{n}}\left[\mathrm{N} / \mathrm{mm}^{2}\right]$ は、(3)式のように 規定されている。

$$
{ }_{m} F_{n}^{\prime}=\alpha_{T}\left(F_{q}+{ }_{m} T M_{n}\right)
$$

ここで $\quad \alpha \mathrm{T}$ ：予想最高温度による強度の補正係数、 $\mathrm{F}_{\mathrm{q}}$ : 品質基準 強度 $\left[\mathrm{N} / \mathrm{mm}^{2}\right] 、 \mathrm{~m}^{\mathrm{T}} \mathrm{M}_{\mathrm{n}}$ ：予想平均盖生温度による強度の補正值 $\left[\mathrm{N} / \mathrm{mm}^{2}\right]$

$F_{\mathrm{q}}$ は $\mathrm{F}_{\mathrm{c}}$ に、構造体コンクリートの強度と、構造体と類似の温度履
歴を与えた管理用供試体の強度との差を考慮した割増し $\Delta \mathrm{F}\left[\mathrm{N} / \mathrm{mm}^{2}\right]$ を加えたものであるので、(3)式は(4)式になる。

$$
{ }_{\mathrm{m}} \mathrm{F}_{\mathrm{n}}=\alpha_{\mathrm{T}}\left(\mathrm{F}_{\mathrm{c}}+\Delta \mathrm{F}+{ }_{\mathrm{m}} \mathrm{TM}_{\mathrm{n}}\right)
$$

ここでは、まず、実験により得られた材齢 $\mathrm{m}$ 日での標準養生供試 体の強度を養生温度補正強度とし、後述する補正係数および補正值 を用いて(4)式を変形した(5)式から材齢 $\mathrm{n}$ 日において期待される構 造体強度 ${ }_{\mathrm{n}} \mathrm{F}_{\text {call }}$ を算出寸る。そして、求めた $\mathrm{n}_{\mathrm{n}}$ calk と材齢 $\mathrm{m}$ 日での標 準養生供試体の強度 ${ }_{\mathrm{m}} \mathrm{F}$ stnd との差として養生温度補正強度の考え方 に基づく補正値 ${ }_{\mathrm{m}} \mathrm{S}_{\mathrm{n}}$ を(6)式によって算出する。

$$
\begin{aligned}
{ }_{\mathrm{n}} \mathrm{F}_{\text {cale }} & =\left({ }_{\mathrm{m}} \mathrm{F}_{\text {stnd }} / \alpha_{\mathrm{T}}\right)-\left(\Delta \mathrm{F}+{ }_{\mathrm{m}} \mathrm{TM}_{\mathrm{n}}\right) \cdots \\
{ }_{\mathrm{m} S}{ }_{\mathrm{n}} & ={ }_{\mathrm{m}} \mathrm{F}_{\text {stnd }}-{ }_{\mathrm{n}} \mathrm{F}_{\text {call }} \\
& ={ }_{\mathrm{m}} \mathrm{F}_{\text {stnd }}(1-1 / \alpha \mathrm{T})+\left(\Delta \mathrm{F}+{ }_{\mathrm{m}} \mathrm{TM}_{\mathrm{n}}\right)
\end{aligned}
$$

（1）予想最高温度による強度の補正係数 $\alpha$ 个

補正係数 $\alpha$ 个注、セメント種類ごとに、構造体コンクリートの強度 管理材齢 $\mathrm{n}$ およびコンクリートの打込みから材齢 $\mathrm{n}$ 日までの期間中 において予想される部材断面内の最高温度によって決まる。FB、M およびMFについてはJASS5N 解説に補正係数 $\alpha_{\top}$ の目安が示され ており、FCおよびLについては、筆者ら 10.11が提案している。こ こでは、「予想最高温度」を「コア供試体採取位置での最高温度」と 読み替え、(7)式および表 2 により補正係数 $\alpha$ 个を算出する。

$$
\alpha \mathrm{r}=1+\mathrm{a}\left(\mathrm{T}_{\max }-\mathrm{T}_{0}\right)
$$

ここで $\mathrm{a}$ : セメント種類および構造体コンクリートの強度管理材 齢 $\mathrm{n}$ によって決まる定数（表 2)、 $\mathrm{T}_{\max }$ : コア供試体採取位置で の最高温度 $\left[{ }^{\circ} \mathrm{C}\right] 、 \mathrm{~T}_{0} ： \alpha$ 下による補正が必要となる最高温度の下 限值 $\left[{ }^{\circ} \mathrm{C}\right]$ （表 2)

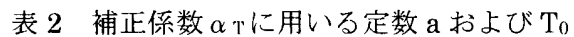

\begin{tabular}{|c|cc|c|}
\hline \multirow{2}{*}{$\begin{array}{c}\text { セメント } \\
\text { 種類 }\end{array}$} & \multicolumn{2}{|c|}{ 定数 $\mathrm{a}$} & $\mathrm{T}_{0}\left({ }^{\circ} \mathrm{C}\right)$ \\
\hline $\mathrm{FB}$ & $\mathrm{n}=28$ & $\mathrm{n}=91$ & \\
\hline $\mathrm{FC}$ & 0 & 0.0094 & 60 \\
$\mathrm{M}$ & 0 & 0.0066 & 40 \\
\hline $\mathrm{MF}$ & 0 & 0.0094 & 60 \\
\hline $\mathrm{L}$ & 0 & 0.0094 & 60 \\
\hline
\end{tabular}

（2）構造体強度と管理用供試体強度との差を考慮した割増し $\Delta \mathrm{F}$ JASS5N では設計基準強度が $36 \mathrm{~N} / \mathrm{mm}^{2}$ 以下で、特記がない場合 の割増し $\Delta \mathrm{F}$ は一律 $3 \mathrm{~N} / \mathrm{mm}^{2}$ と規定されている。これはJASS5 の規 定を踏襲しているが、ここでは既往研究 7).10).11)に基づく平均的な割 増しとしてセメント種類ごとに(8-1)〜(8-5)式から算出する。

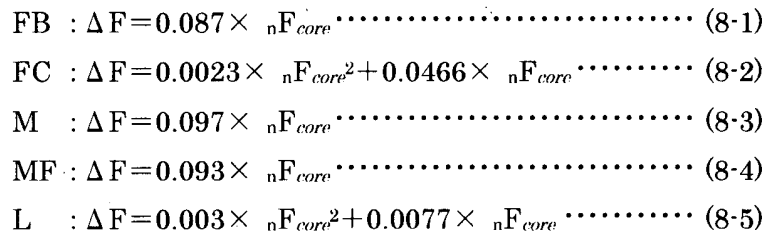

（3）予想平均養生温度による強度の補正值 $\mathrm{m}_{\mathrm{m}} \mathrm{TM}_{n}$

補正値 $\mathrm{m}_{\mathrm{T}} \mathrm{T} \mathrm{n}_{\mathrm{n}}$ は、セメント種類ごとに、調合強度を定める材齢 $\mathrm{m}$ と構造体コンクリートの強度管理材齢 $\mathrm{n}$ およびコンクリートの打込 みから材龄 $\mathrm{n}$ 日までの期間の予想平均養生温度によって決まる。 $\mathrm{FB}$ 、 M およびMFについては、JASS5 に標準值が規定されており、FC およびしについては筆者らは111が提案している。表 3 に本検討に用 
いる $\mathrm{m}_{\mathrm{TM}}$ とそれに対応する予想平均養生温度の範囲を示す。ここ では標準養生供試体の強度試験材齢を: $\mathrm{m} 、 コ ア$ 供試体の強度試験材 齢を $\mathrm{n}$ とし、「予想平均盖生温度」を「コア供試体採取位置での打込 みから材歯 $\mathrm{n}$ 日までの期間の平均盖生温度」と読み替え、表 3 に基 づき $\mathrm{mTM}_{\mathrm{n}}$ を求める。なお、本検討では、平均養生温度が JASS5N 標準値および参考文献 10.11 提案值の $6 \mathrm{~N} / \mathrm{mm}^{2}$ の温度範囲を下回る場 合は、 $\mathrm{m}_{\mathrm{TM}}$ を $9 \mathrm{~N} / \mathrm{mm}^{2}$ とする。

表 3 予想平均養生温度による強度の補正值 $\mathrm{m}_{\mathrm{m}} \mathrm{TM}_{\mathrm{n}}$

\begin{tabular}{|c|c|c|c|c|c|c|c|}
\hline $\begin{array}{l}\text { セxン } \\
\text { 種類 }\end{array}$ & $\begin{array}{c}\mathrm{m} \\
(\text { 日) }\end{array}$ & $\begin{array}{c}\mathrm{n} \\
\text { (日) }\end{array}$ & \multicolumn{5}{|c|}{ 予想平均養生温度 $の$ 範囲 $\left({ }^{\circ} \mathrm{C}\right)$} \\
\hline \multirow{4}{*}{ FB } & \multirow{2}{*}{28} & 28 & 16 以上 & 9 & $\sim 16$ & 4 & $\sim 9$ \\
\hline & & 91 & 2 以上 & & - & & - \\
\hline & 56 & 91 & 7 以上 & 3 & $\sim 7$ & 2 & $\sim 3$ \\
\hline & 91 & 91 & 17 以上 & 10 & $\sim 17$ & 6 & $\sim 10$ \\
\hline \multirow{4}{*}{$\mathrm{FC}$} & \multirow{2}{*}{28} & 28 & 16 以上 & 10 & $\sim 16$ & 6 & $\sim 10$ \\
\hline & & 91 & 2 以上 & & - & & - \\
\hline & 56 & 91 & 6 以上 & 2 & $\sim 6$ & & - \\
\hline & 91 & 91 & 16 以上 & 10 & $\sim 16$ & 6 & $\sim 10$ \\
\hline \multirow{4}{*}{ M } & \multirow{2}{*}{28} & 28 & 17 以上 & 13 & $\sim 17$ & 9 & $\sim 13$ \\
\hline & & 91 & 2 以上 & & - & & - \\
\hline & 56 & 91 & 7 以上 & 4 & $\sim 7$ & 2 & $\sim 4$ \\
\hline & 91 & 91 & 17 以上 & 13 & $\sim 17$ & 9 & $\sim 13$ \\
\hline \multirow{4}{*}{$\mathrm{MF}$} & \multirow{2}{*}{28} & 28 & 18 以上 & 14 & $\sim 18$ & 10 & $\sim 14$ \\
\hline & & 91 & 2 以上 & & - & & - \\
\hline & 56 & 91 & 8 以上 & 5 & $\sim 8$ & 3 & $\sim 5$ \\
\hline & 91 & 91 & 18 以上 & 14 & $\sim 18$ & 10 & $\sim 14$ \\
\hline \multirow{4}{*}{$\mathrm{L}$} & \multirow{2}{*}{28} & 28 & 18 以上 & 15 & $\sim 18$ & 12 & $\sim 15$ \\
\hline & & 91 & 2 以上 & & -- & & - \\
\hline & 56 & 91 & 7 以上 & 5 & $\sim 7$ & 4 & $\sim 5$ \\
\hline & 91 & 91 & 18 以上 & 15 & $\sim 18$ & 12 & $\sim 15$ \\
\hline \multicolumn{3}{|c|}{$\left(\mathrm{N} / \mathrm{mm}^{2}\right)$} & 0 & & 3 & & 6 \\
\hline
\end{tabular}

\section{4. 検討結果および考察}

$\mathrm{S}$ 値には種々の要因による補正が含まれているため、既往研究 33.12 において S 值は、平均養生温度、最高温度、コア供試体の強度等を バラメータとして評価されている。本検愔で対象としているのは低 発熱形セメントであり、かつ、水セメント比が $40 \sim 55 \%$ あるること から、コア供試体採取位置での最高温度が、一般に長期材龄での強 度増進への影響が顕著になると言われる $60^{\circ} \mathrm{C}$ を回るデータが全 体の約 $15 \%$ に過ぎない。一方、平均盖生温度が $20{ }^{\circ} \mathrm{C}$ を回るデータ は全体の約 $60 \%$ を占めている。

以上より、本検楌では各種の要因のうち構造体コンクリートの強 度発現に与える影響が最も大きいと考えられる平均養生温度を主な パラメータとして検討する。

\section{1 水セメント比の違いによる比較}

図 1 に、打込みから材龄 91 日までの期間の平均養生温度と ${ }_{5}\left(\mathrm{~S}_{91}\right.$ の関倸をセメント種類ごとに示す。 $\mathrm{M}$ および MFに掠いて、水セメ ント比が $40 \%$ の場合に ${ }_{56} \mathrm{~S}_{91}$ が若干大きくなる傾向が認められるが、 水セメント比ごとに区分できるほど明確な差異ではない。その他の セメント種類については、水セメント比ごとの差異は認められない。 なお、これらの傾向は他の $\mathrm{m}$ と $\mathrm{n}$ の組合せについてもほぼ同様であ る。

上述のように、対象としている水セメント比の範囲におういて、補 正值 ${ }_{\mathrm{m}} \mathrm{S}_{\mathrm{n}}$ を水セメント比ごとに区分することが困難であること、ま た、JASS5N では、養生温度補正強度による調合強度の補正に用い る補正値等を水セメント比によって区分していないことを踏まえ、
これ以降の検討では水セメント比によって区分しないものとする。

\section{2 構造体補正強度による補正}

図 2 に、打込みから材龄 $\mathrm{n}$ 日までの期間の平均盖生温度と補正值 $\mathrm{mS}_{\mathrm{n}}$ の関係を $\mathrm{m}$ と $\mathrm{n}$ の組合せごとに示す。

$\mathrm{m}=28 、 \mathrm{n}=28$ の場合、 L 以外のセメントでは平均養生温度に関倸 なく補正值は概ね $0 \sim 10 \mathrm{~N} / \mathrm{mm}^{2}$ の範囲に分布しているが、Lでは平 均盖生温度が概ね $10^{\circ} \mathrm{C}$ を回る範囲において、 ${ }_{28} \mathrm{~S}_{28}$ が大きくなって いる。これは、低熱ポルトランドセメントを使用した構造体コンク リートを低温で養生した場合に初期材龉での強度が同一積算温度で の標準養生供試体の強度より低くなる現象に起因していると考えら れる。この現象はビーライトの水和の温度依存性による 13 もものと推 測され、既往実験 14)のデータでも確認されている。なお、筆者ら 11 は、この現象が確認できる積算温度の範囲を概ね $1,000{ }^{\circ} \mathrm{D} \cdot \mathrm{D}$ 以下 としている。

$\mathrm{n}=91$ の場合、 ${ }_{2 x} \mathrm{~S}_{911}$ では ${ }_{28} \mathrm{~S}_{28}$ で見られるような、平均養生温度が $10^{\circ} \mathrm{C}$ 付近で上の補正值のみが大きくなる傾向は見られない。これは 材齢 $\mathrm{n}$ が大きくなったことによって積算温度が $1,000^{\circ} \mathrm{D} ・ \mathrm{D}$ を超え
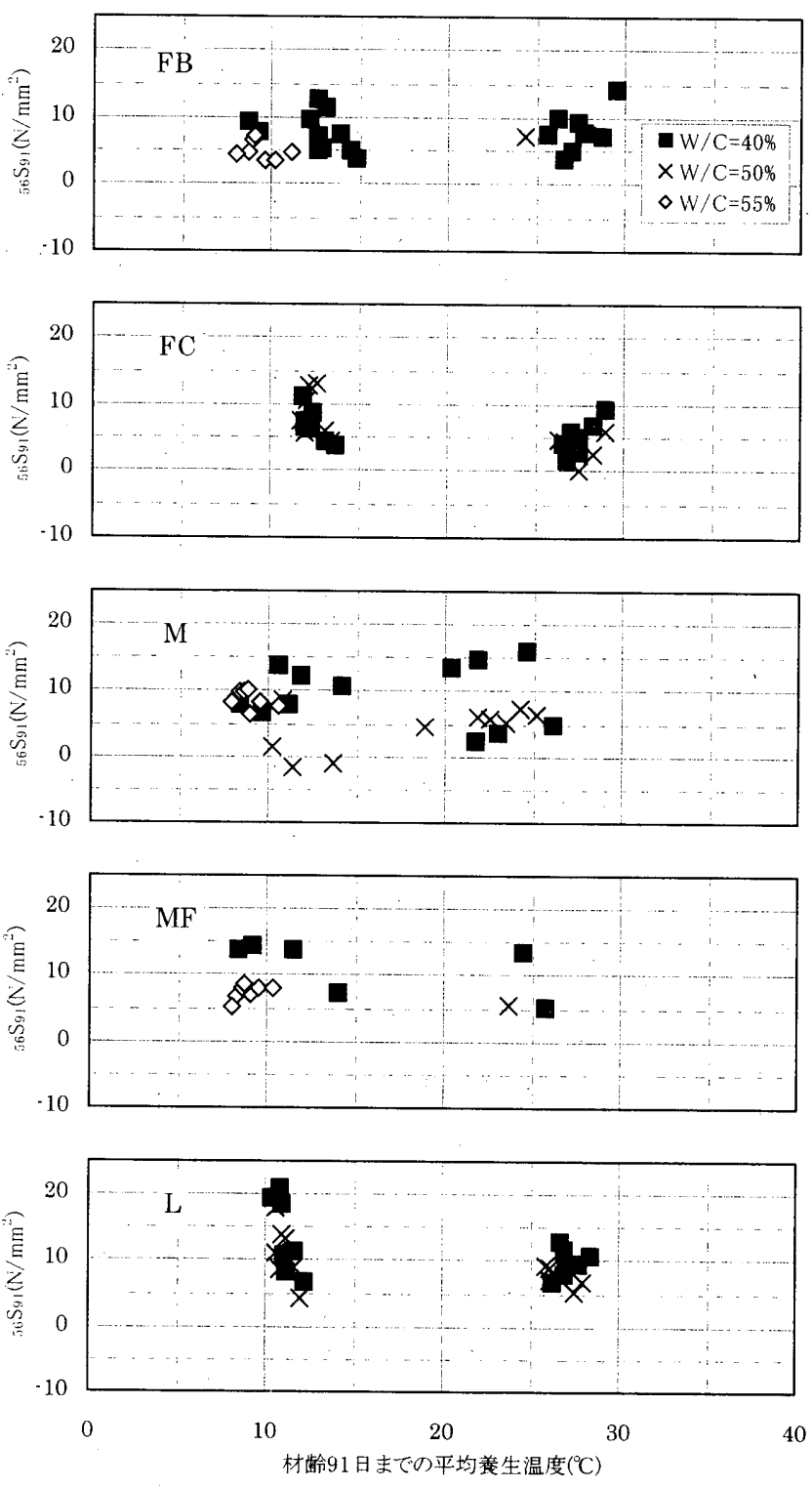

図 1 セメント種類ごとの平均養生温度と補正值 $56 \mathrm{~S}_{91}$ の関倸 
たためと考えられる。また、 $\mathrm{m}$ が大きくなるにつれて全体的に補正 值が大きくなる傾向にある。その傾向は、特に L で顕著であり、 ${ }_{11} \mathrm{~S}_{91}$ が $30 \mathrm{~N} / \mathrm{mm}^{2}$ 程度になっているものもある。これは標準養生供試体 の強度が材齢 28 日以降も長期にわたって增進していることを示し ており、特に低熱ポルトランドセメントを使用した場合は、積算温 度が $1,000^{\circ} \mathrm{D} \cdot \mathrm{D}$ 以上の範囲での強度増進がその他のセメント以上
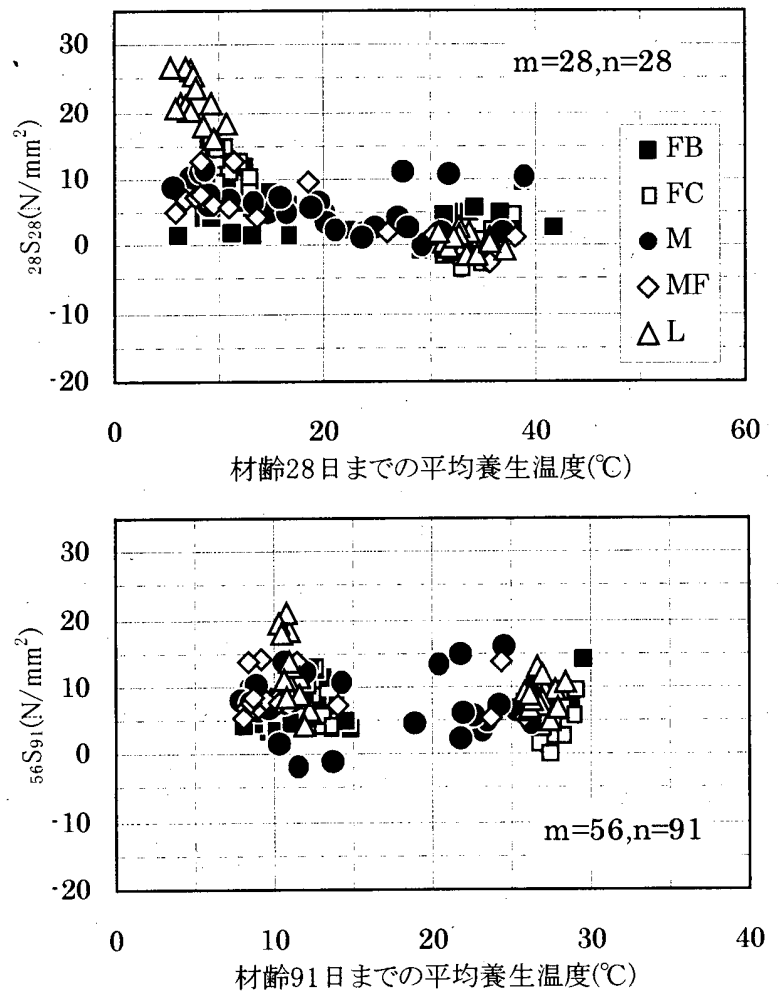

に大きい11ためであると考えられる。

\section{3 養生温度補正強度による補正}

図 3 に、打込みから材齢 $\mathrm{n}$ 日までの期間の平均養生温度と補正值 ${ }_{\mathrm{m} S}{ }_{\mathrm{n}}$ の関係を $\mathrm{m}$ と $\mathrm{n}$ の組合せごとに示す。

$\mathrm{m}=28 、 \mathrm{n}=28$ の場合、平均養生温度が $10^{\circ} \mathrm{C}$ 付近では、L以外のセ メントの ${ }_{28} \mathrm{~S}_{28}$ は、図 2 の ${ }_{28} \mathrm{~S}_{28}$ とほぼ同等であるが、図 2 で見られ
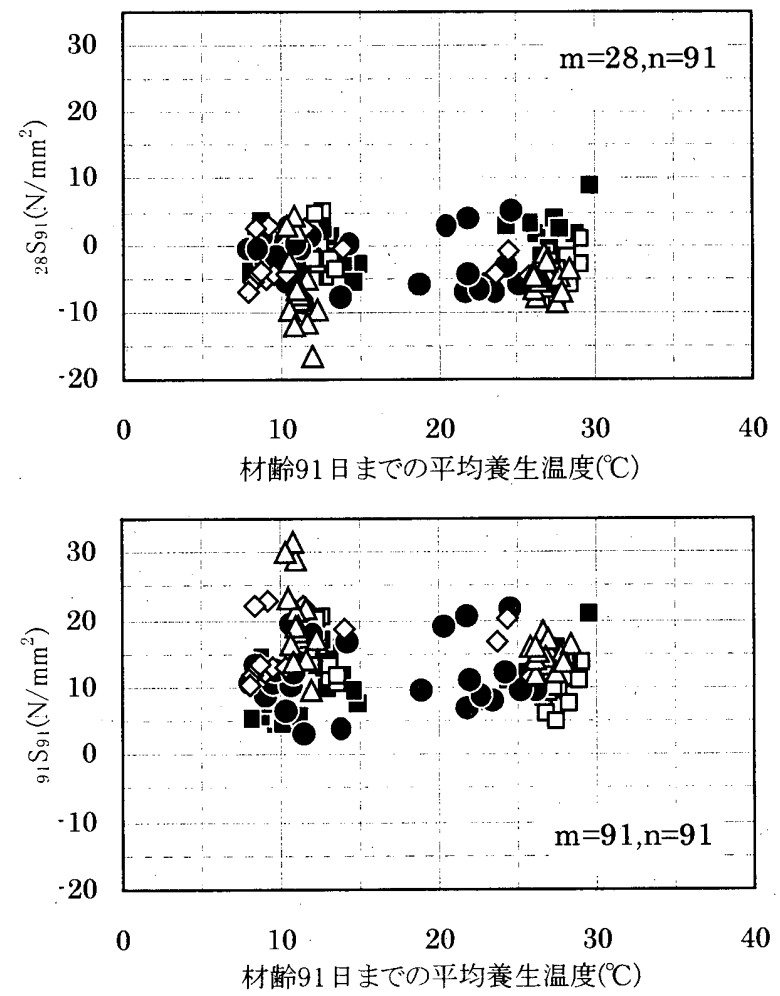

図 2 平均養生温度と補正值 $\mathrm{mS}_{\mathrm{n}}$ の関係
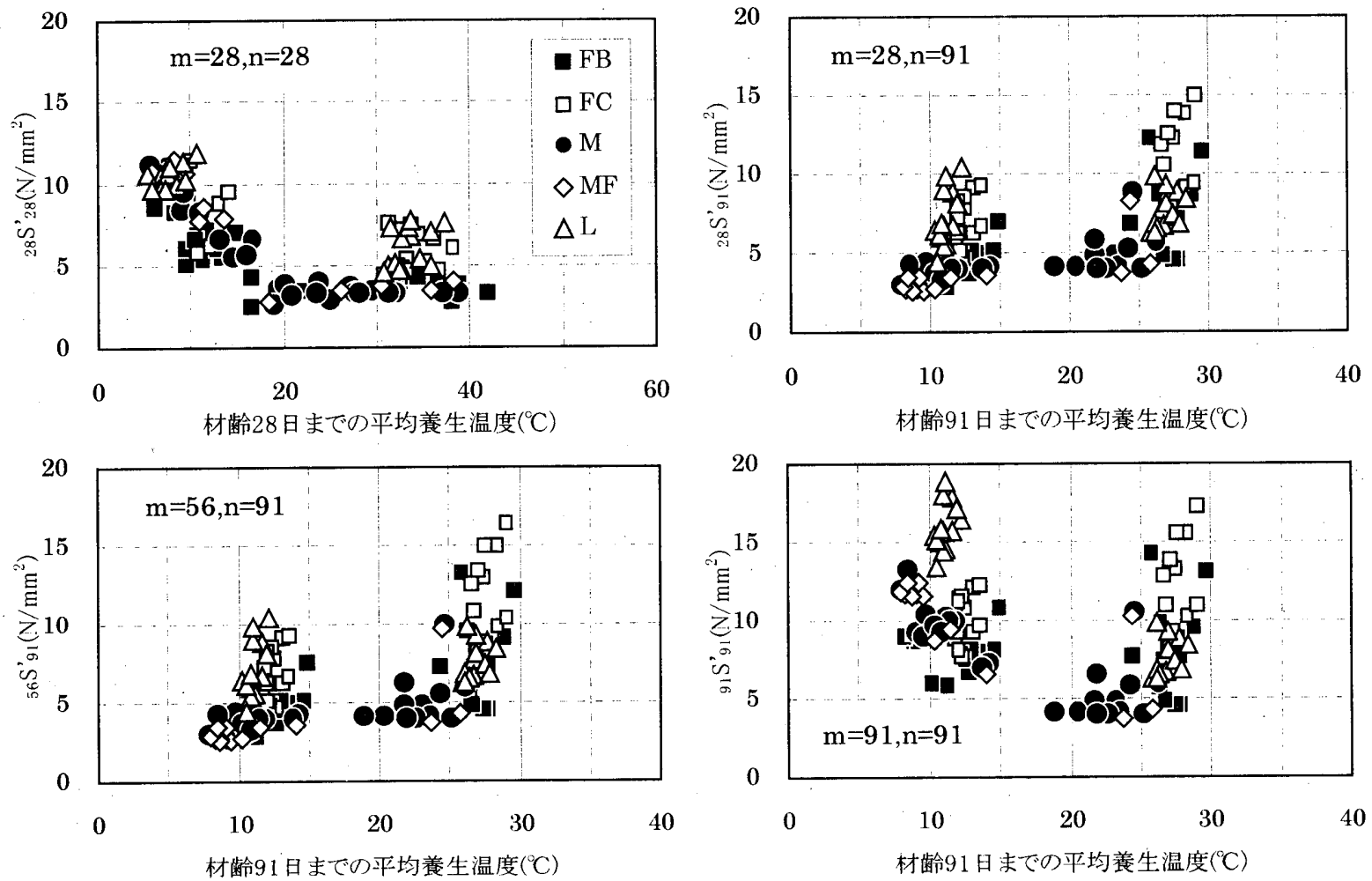

図 3 平均養生温度と補正值 $\mathrm{mS}_{\mathrm{n}}{ }_{\mathrm{n}} \dot{\text { d }}$ 関保 

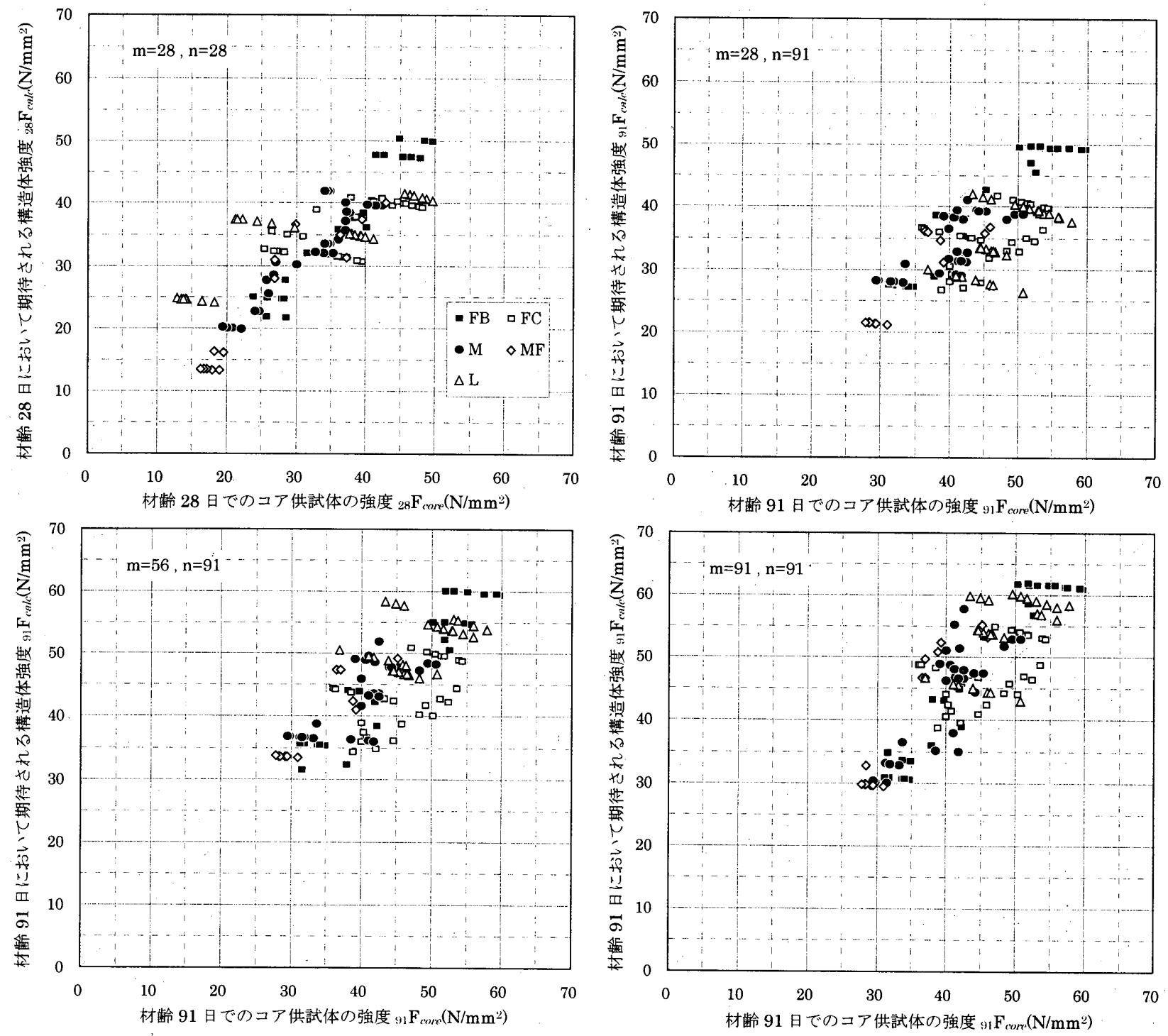

図 4 材齢 $\mathrm{n}$ 日でのコア供試体の強度 ${ }_{n} \mathrm{~F}_{\text {core }}$ と材齢 $\mathrm{n}$ 日において期待される構造体強度 ${ }_{\mathrm{n}} \mathrm{F}_{\text {calc }}$ の関倸

たような Lの補正值のみが他のセメントより大きくなる傾向は現れ ていない。この理由としては、既往研究 8).10).11)では、従来の積算温 度の考え方に基づき補正值 $\mathrm{m}_{\mathrm{TM}}$ 在求めているため、盖生温度が低 い場合に積算温度が小さい範囲で標準養生供試体の強度より低くな る低熱ポルトランドセメントの特性が ${ }_{28} \mathrm{TM} 28$ に反映できていない 11)ことが挙げられる。

$\mathrm{n}=91$ の場合、 $\mathrm{m}$ が大きくなっても、全体的には図 2 で見られた ほど補正值が大きくはならないが、平均養生温度が $10 \sim 15^{\circ} \mathrm{C}$ 範囲 において、特にLの場合に: $\mathrm{m}$ が大きくなるにつれて補正值が大き くなる傾向は図 2 と同様である。また、平均養生温度が $25^{\circ} \mathrm{C}$ 以上の 範囲で FB および FC の補正值のばらつきが大きくなっている。こ れは平均養生温度が高い場合、最高温度も高くなることが多いため、 本検討で対象としているセメント種類の中で比較的水和熱が大きい $\mathrm{FB}$ と、最高温度 $40^{\circ} \mathrm{C}$ 以上で補正を行っている FCについては、補 正係数 $\alpha$ Tよよる補正が影響しているものと考えられる。

\section{4 養生温度補正強度の適用性}

図 4 に、材齢 $\mathrm{n}$ 日でのコア供試体の強度 $\mathrm{n}_{\mathrm{F}} \mathrm{core}$ と、このコア供試 体と同時に製作し、材齡 $\mathrm{m}$ 日まで標準養生した供試体の強度から(5)
式によって計算した材齢 $\mathrm{n}$ 日において期待される構造体強度 ${ }_{n} \mathrm{~F}_{\text {calc }}$ との関係を示す。

$\mathrm{m}=28 、 \mathrm{n}=28$ の場合、 ${ }_{28} \mathrm{~F}_{\text {core }}$ と ${ }_{28} \mathrm{~F}_{\text {calc }}$ はほぼ同等であるが、L では ${ }_{28} \mathrm{~F}_{\text {core }}$ が ${ }_{28} \mathrm{~F}_{\text {call }}$ を大きく下回るデータがある。これは図 2 および図 3 において平均養生温度が $10^{\circ} \mathrm{C}$ を回るデータである。一方、 $\mathrm{n}=91$ の場合、セメント種類による差異は明確に認められず、ばらつきは 大きいものの、平均的に $\mathrm{m}=28$ では ${ }_{91} \mathrm{~F}_{\text {core }}$ が ${ }_{91} \mathrm{~F}_{\text {calc }}$ より大きくなり、 $\mathrm{m}=56$ では両者はほぼ同等、 $\mathrm{m}=91$ では ${ }_{91} \mathrm{~F}_{\text {core }}$ が ${ }_{91} \mathrm{~F}_{\text {calc }}$ より小さく なる傾向が認められる。

次に、3.1 に基づき算出した補正值 $\mathrm{m}_{\mathrm{n}}$ と 3.2 に基づき算出した補 正值 $\mathrm{mS}_{\mathrm{n}}$ の関係を図 5 に示す。 $\mathrm{m}=28 、 \mathrm{n}=28$ の場合、 ${ }_{28} \mathrm{~S}_{28}^{\prime}$ と ${ }_{28} \mathrm{~S}_{28}$ はほぼ同等であるが、L では ${ }_{28} \mathrm{~S}_{28}{ }_{28}{ }_{28} \mathrm{~S}_{28}$ を大きく下回るデータが ある。

$\mathrm{n}=91$ の場合、 $\mathrm{m}=28$ では構造体コンクリートの強度が標準養生供 試体の強度を上回っているため ${ }_{28} \mathrm{~S}_{91}$ のほとんどが負の値であるが、 $\mathrm{m}$ が大きくなるとともに標準養生供試体の強度が増進するため $\mathrm{m} \mathrm{S}_{91}$ は大きくなり、m=56 および $\mathrm{m}=91$ では正の值となっている。一方、 ${ }{ }_{n} \mathrm{~S}_{91}{ }_{91}$ は、算出の基となっている補正值および補正係数が全て正の值 

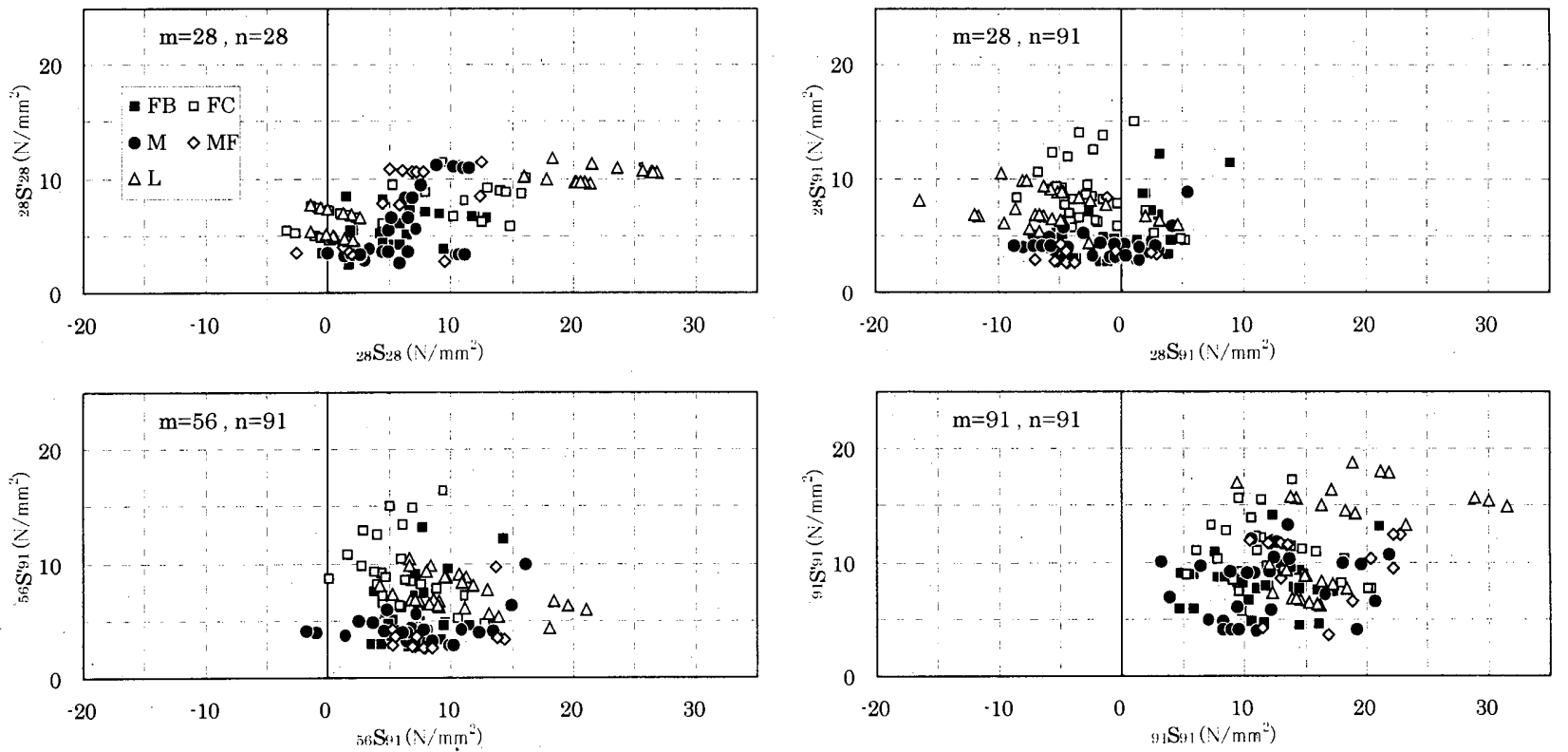

図 5 補正値 $\mathrm{mS}_{\mathrm{n}}$ と補正值 $\mathrm{m}_{\mathrm{n}}{ }_{\mathrm{n}}$ の関係

であることから、 $\mathrm{m}=28$ においても全て正の値となり、 $\mathrm{m}$ が大きく なるとともにその值は大きくなる傾向にあるが、 $\mathrm{m}$ の増加に対する ${ }_{\mathrm{m}} \mathrm{S}_{91}$ の増加の程度は、 $\mathrm{mS}_{91}$ のそれに比べて小さい。その結果、 $\mathrm{m}=28$ では ${ }_{28} \mathrm{~S}_{91}$ が ${ }_{28} \mathrm{~S}_{91}$ より大きく、 $\mathrm{m}=56$ では活 $\mathrm{S}_{91}$ と ${ }_{56} \mathrm{~S}_{91}$ はほぼ同等、 $\mathrm{m}=91$ では ${ }_{91} \mathrm{~S}_{91}$ が $_{91} \mathrm{~S}_{91}$ より小さくなっている。

以上より、調合強度を定める材齢 $\mathrm{m}$ および構造体コンクリートの 強度管理材㱓 $\mathrm{n}$ をともに 28 日とする場合、養生温度補正強度によ る補正は、構造体補正強度による補正とほぼ同等の補正を行うこと ができるが、低熱ポルトランドセメントを使用する場合には、養生 温度が低いと構造体コンクリートの強度が調合において期待される 強度を下回ることがあるので、コンクリートの打込み時期や温度管 理には留意する必要がある。また、構造体コンクリートの強度管理 材齢 $\mathrm{n}$ を 91 日にする場合、調合強度を定める材齢 $\mathrm{m}$ を 28 日とし て養生温度補正強度によって補正すると、実際には必要のない補正 を行うことになる。これは、調合強度を定める材齢 $\mathrm{m}$ を延長するこ とで解消されるが、材齢 $\mathrm{m}$ の延長に伴い、実際に必要な補正值が増 加する割合に対して、養生温度補正強度によって算出する補正值が 増加する割合が小さいため、調合強度を定める材歯を 91 日まで延長 すると、養生温度補正強度によって算出する補正值が実際に必要な 補正值を下回り、調合強度の補正としては危険側に過小評価してし まう可能性が高くなる。

これらより勘案すると、本検討で対象とした低発熱形セメントを 使用寸る場合、構造体コンクリートの強度管理材齡 $\mathrm{n}$ は、長期材齢 での強度増進が期待できるため、91日まで延長することが望ましい。 また、構造体コンクリートの強度管理材齢 $\mathrm{n}$ を 91 日とし、養生温 度補正強度によって調合強度を補正する場合、調合強度を定める材 齢 $\mathrm{m}$ を 56 日とすると、構造体補正強度による補正とほぼ同等の補 正ができると言える。

\section{5. 結 論}

本検討では、実験資料に基づき低発熱形セメントを使用したマス コンクリートの調合強度の補正について検討した結果、以下のこと
が明らかになった。

（1）いずれのセメント種類においても、水セメント比が 40～55\%の 範囲では、水セメント比ごとに補正值を区分することは困難であ る。

（2）低熱ポルトランドセメントを使用し、構造体コンクリートの強 度管理材齢を 28 日として養生温度補正強度によって調合強度を 補正寸る場合、養生温度が低いと構造体コンクリートの強度が調 合において期待される強度を下回る可能性がある。

（3）構造体コンクリートの強度管理材齢を 91 日として養生温度補 正強度によって調合強度を補正する場合、調合強度を定める材龄 を 28 日とすると、実際に性必要のない補正をすることになる。 一方、調合強度を定める材齢を 91 日まで延長すると、実際に必 要な補正値を危険側に過小評価してしまう可能性が高い。

（4）養生温度補正強度によって調合強度を補正する場合、調合強度 を定める材齢を 56 日、構造体コンクリートの強度管理材齢を 91 日とすると、構造体補正強度による補正とほぼ同等の補正ができ る。

なお、本検討は既往研究の実験データから平均的な補正值を算出 することにより、調合強度の補正方法とその傾向について考察した ものである。実際に調合強度を定める場合には、補正係数および補 正値の具体的な值を設定する段階や調合強度から水セメント比を設 定する段階において、適度な安全余裕を見込む必要がある。

\section{参考文献}

1) 日本建築学会:建築工事標準仕様書·同解説 JASS5N 原子力発電所施設に おりる鉄筋コンクリート工事, 2001.5

2）日本建築学会:建築工事標準仕様書・同解説 JASS5 鉄筋ロンクリート工事, 2003.2

3) 例えば、立松和彦ほか3 名:簡易断熱盖生による高強度コンクリートの構造体強 度の品質管理打よび $\mathrm{S}$ 值,日本建築学会技術報告集,No15,pp.11·14,2002.6

4) 仕入豊和ほか２名:マッッシブなコンクリートの予想平均養生温度おらで強度発現 に関する研究,セメント・コンクリート,No.499,pp.35-48, 1988.9

5）仕入豊和ほか 6 名:マッシブなコンクリートの予想平均養生温度および強度発現 関寸る研究 第 1 報〜第 4 報, 日本建築学会大会学術講演梗概集(近畿), pp.211-218, 1987.10 
6）仕入豊和ほか 5 名:高強度マスコンクリートの構造体の予想平均養生温度およ び強度発現に関する研究 第 1 報〜第 4 報, 日本建築学会大会学術講演梗概 集(九州),pp.525-532,1989.10

7）桝田佳寛ほか33名:低発熱形セメントを用いたマスコンクリートの強度発現性々調 合強度の補正, 日本建築学会構造系論文集,No.533,pp.7·12,2000.7

8）桝田佳寛ほか 3 名:低発熱形セメントを用いたコンクリートの平均養生温度によ る強度補正值, 日本建築学会構造系論文集,No.535,pp.7·12,2000.9

9）嵩英雄ほか 4 名: 低発熱形セメントを用いた構造体コンクリートの強度発現性に 関する研究 その 1 その 3 , 日本建築学会大会学術講演梗概集(東北), pp.801-806,2000.9

10）池内俊之ほか 3 名:フライアッシュを使用したマスコンクリーートの強度発現性と調 合強度の補正, 日本建築学会構造系論文集,No.560,pp.9·16,2002.10
11)池内俊之ほか 3 名:低熱ボルトランドセメントを使用したマスコンクリートの強度発 現性と調合強度の補正, 日本建築学会構造系論文集, No.566,pp.21·27, 2003.4

12）例えば、西村進ほか 2 名:高強度コンクリートへの低熱ポルトランドセメントの適 応性について(その 3.構造体シンクリートの強度発現性状), 日本建築学会大会 学術講演梗概集(東北),pp.917·918,2000.9

13）浅賀喜与志,大門正機，小西和夫,吉田孝三郎:低熱セメントの各構成鉱物の水 和反忘に及ぼす養生温度の影響, セメント・コンクリ一ト論文集,No.45,pp.58-63, 1991

14）セメント協会:高ビーライト系セメントを用いた高性能コンクリートの性能評価に関 寸る研究,建築用高性能コンクリート専門委員会報告,pp.26·76,1997.3 